BNL-114541-2017-IR

CBETA/009

February 2017

\title{
FFAG Cell Candidate February 2017
}

\author{
S. Brooks
}

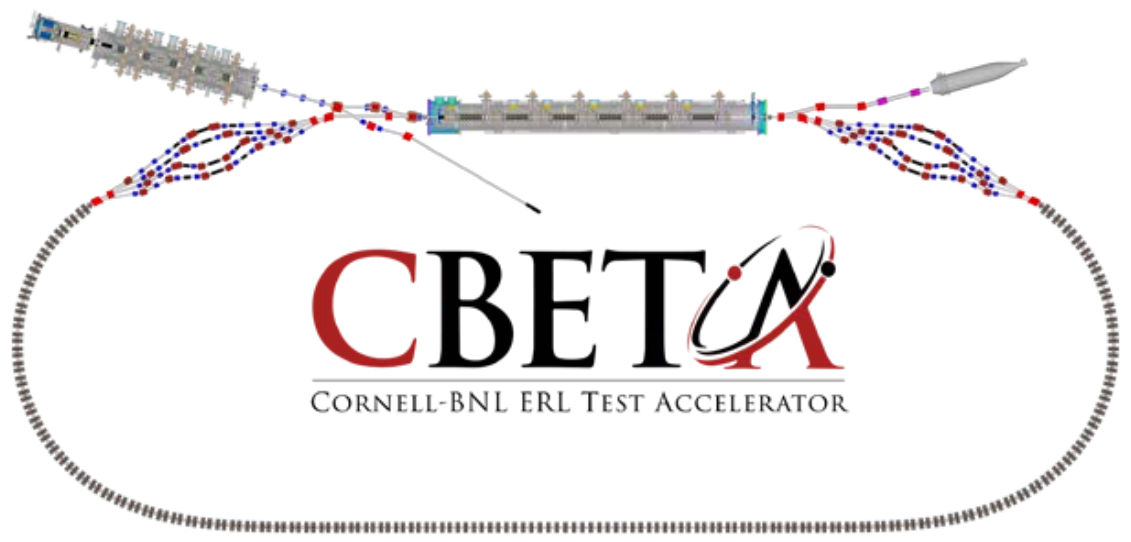

Collider-Accelerator Department, Brookhaven National Laboratory, Upton NY 11973

U.S. Department of Energy

Office of Science, Office of Nuclear Physics

Cornell Laboratory for Accelerator-Based Sciences and Education, Ithaca, NY 14850

Funded by NYSERDA contract 102192

Notice: This document has been authorized by employees of Brookhaven Science Associates, LLC under Contract No. DE-SC0012704 with the U.S. Department of Energy. The United States Government retains a non-exclusive, paid-up, irrevocable, world-wide license to publishor reproduce the published form of this document, or allow others to do so, for United States Government purposes. 


\section{DISCLAIMER}

This report was prepared as an account of work sponsored by an agency of the United States Government. Neither the United States Government nor any agency thereof, nor any of their employees, nor any of their contractors, subcontractors, or their employees, makes any warranty, express or implied, or assumes any legal liability or responsibility for the accuracy, completeness, or any third party's use or the results of such use of any information, apparatus, product, or process disclosed, or represents that its use would not infringe privately owned rights. Reference herein to any specific commercial product, process, or service by trade name, trademark, manufacturer, or otherwise, does not necessarily constitute or imply its endorsement, recommendation, or favoring by the United States Government or any agency thereof or its contractors or subcontractors. The views and opinions of authors expressed herein do not necessarily state or reflect those of the United States Government or any agency thereof. 


\section{FFAG Cell Candidate February 2017}

Stephen Brooks

2017-Feb-23

CBETA machine note \#9

\section{Summary}

The magnets for the CBETA "First Girder" have been ordered on the basis of the FFAG cell given in note [CBETA001]. However, detailed dynamics studies of this cell have shown the $42 \mathrm{MeV}$ energy is close to a $Q_{x}+2 Q_{y}=1$ cell resonance [CBETA007]. The cell intended for the final CBETA machine was therefore retuned to avoid this resonance. The changes are summarised below.

\begin{tabular}{|l|l|l|l|}
\hline Magnet & Parameter & Old value & New value \\
\hline QF & Quadrupole $(\mathrm{T} / \mathrm{m})$ & -11.5 & -11.2 \\
\hline BD & Dipole at centre $(\mathrm{T})$ & -0.311 & -0.309 \\
\hline BD & Quadrupole $(\mathrm{T} / \mathrm{m})$ & 11 & 10.7 \\
\hline
\end{tabular}

As previously, the values in the table above are average values - that is, integrated fields as measured from a single magnet on a rotating coil, divided by the magnet nominal length. Thus, the new magnets can also be specified by their integrated fields given in the table below.

\begin{tabular}{|l|l|l|}
\hline Magnet name & Integrated dipole (T.m) & Integrated quadrupole (T) \\
\hline QF & 0 & -1.49296 \\
\hline BD & -0.0376053 & 1.30219 \\
\hline
\end{tabular}

The lengths of the magnets have stayed the same as before ( $Q F=133.3 \mathrm{~mm}, B D=121.7 \mathrm{~mm}$ ).

The cell geometry is now arranged around a "block-and-straight" design that will be described in other documentation, but the drift lengths are to a good approximation the same. The magnet design will be finalised soon and described in another note.

This cell may or may not be the final CBETA cell, but is intended as our current best working point for further studies to confirm its suitability.

\section{Changes to the Tunes}

This change to the magnet strengths affects the cell tunes in the way shown in the table below. All calculations were done with the Muon1 code using a soft-edged field model falling as $0.5+0.5 * \tanh (z / 2.5 \mathrm{~cm})$ at each end of each magnet.

\begin{tabular}{|l|l|l|l|l|}
\hline $\begin{array}{l}\text { Total Energy } \\
(\mathrm{MeV})\end{array}$ & Old $\mathbf{Q}_{\mathrm{x}}$ & New $\mathbf{Q}_{\mathrm{x}}$ & Old $\mathbf{Q}_{\mathrm{y}}$ & New $\mathbf{Q}_{\mathrm{y}}$ \\
\hline 150 & 0.102835 & 0.100854 & 0.039079 & 0.036222 \\
\hline 114 & 0.126853 & 0.124162 & 0.068072 & 0.064874 \\
\hline 78 & 0.182031 & 0.178065 & 0.128300 & 0.124370 \\
\hline 42 & 0.383192 & 0.366829 & 0.301829 & 0.291162 \\
\hline
\end{tabular}

The main change was to reduce the $42 \mathrm{MeV}$ tunes enough to avoid the $\mathrm{Q}_{x}+2 \mathrm{Q}_{y}=1$ cell resonance. The old cell had $Q_{x}+2 Q_{y}=0.98685$ and the new cell has $Q_{x}+2 Q_{y}=0.94915$, which studies by Scott Berg have 
shown to be a comfortable distance from the resonance, in the sense that it is similar to the distances from other resonances that bound the working region.

\section{Changes to the Orbit Excursions}

Generally speaking, when the cell geometry is held constant, lowering the highest tune or increasing the lowest tune in a non-scaling FFAG cell increases the orbit excursion. Our maximum orbit excursion is in the $Q F$ magnet and the table below shows how the minimum and maximum local $x$ values in the $Q F$ magnet have changed.

\begin{tabular}{|l|l|l|l|}
\hline Cell Version & Local $x_{\min }$ in QF $(\mathrm{mm})$ & Local $x_{\max }$ in QF $(\mathrm{mm})$ & $\begin{array}{l}\text { Distance from 2.75" ID } \\
\text { vacuum pipe }(\mathrm{mm})\end{array}$ \\
\hline Old (first girder) & -21.744 & 21.474 & 13.181 \\
\hline New (February 2017) & -22.696 & 22.755 & 12.170
\end{tabular}

The new cell has $\sim 1 \mathrm{~mm}$ less clearance but still, in this field model, more than the $12 \mathrm{~mm}$ required by the original CBETA specification.

\section{Dynamic Aperture Code Issues}

This resonance initially only appeared in Francois Meot's Zgoubi tracking code, which tries particles of gradually greater amplitudes until it finds a loss.

Scott Berg initially did not see it, but found that making the particle loss condition stricter, to eliminate particles whose amplitude had doubled from the starting amplitude, rather than waiting for the amplitude to tend to infinity, showed the resonance.

Stephen Brooks did not see the resonance at all in Muon1's dynamic aperture study, which used the real beam pipe as the loss condition. However, the Muon1 study counted the entire area of the transmitted beam region as the figure of merit for a given working point. The problem with this became clear when Dejan Trbojevic did a dynamic aperture study in MADX-PTC, resulting in the plot below.

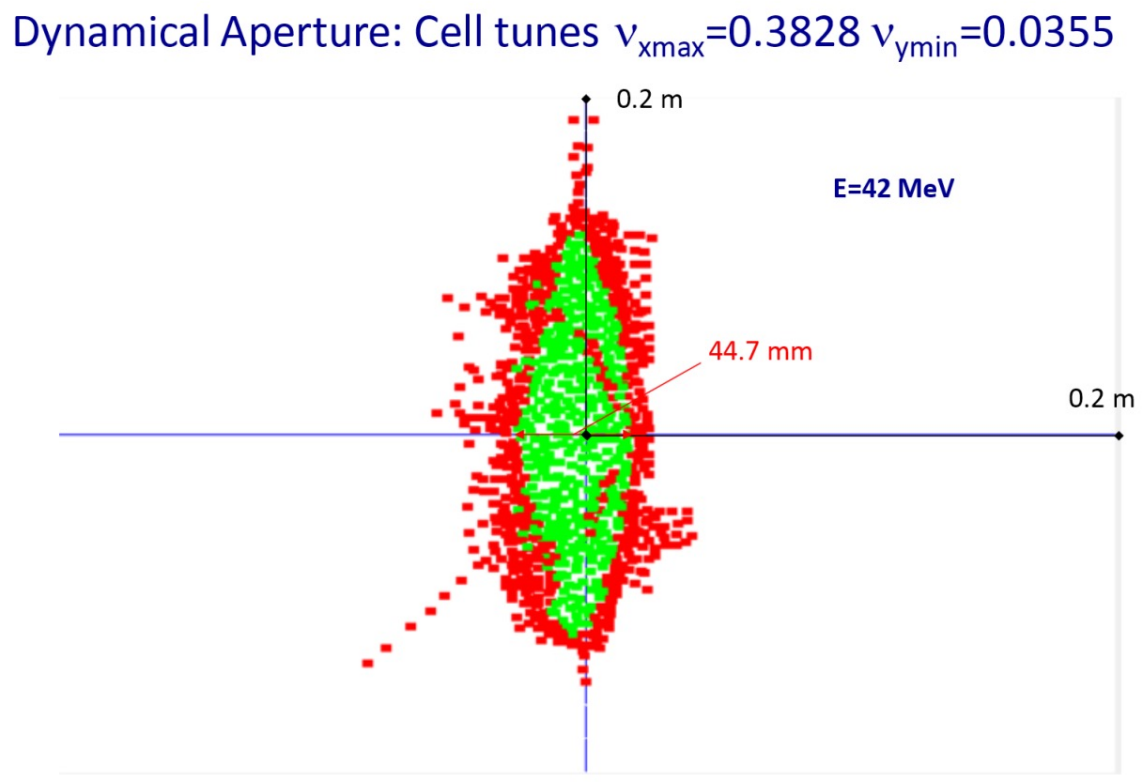


Some of the losses (red) are at smaller amplitudes enclosed inside the overall accepted region. So, the Muon1 study counted the entire green area and did not see the losses at low amplitudes that actually dictate the safe amplitudes for beams. It is planned to rerun the Muon1 study with an updated dynamic aperture definition at a later date.

\section{Appendix: Parameter Space Explored}

Some other combinations of gradients and tunes were tried before settling on this combination. In the spreadsheet below, the two gradients were varied without changing the BD central dipole and the maximum (42MeV horizontal) and minimum (150MeV vertical) tunes were noted, as well as the orbit ranges and likely distance to the beam pipe.

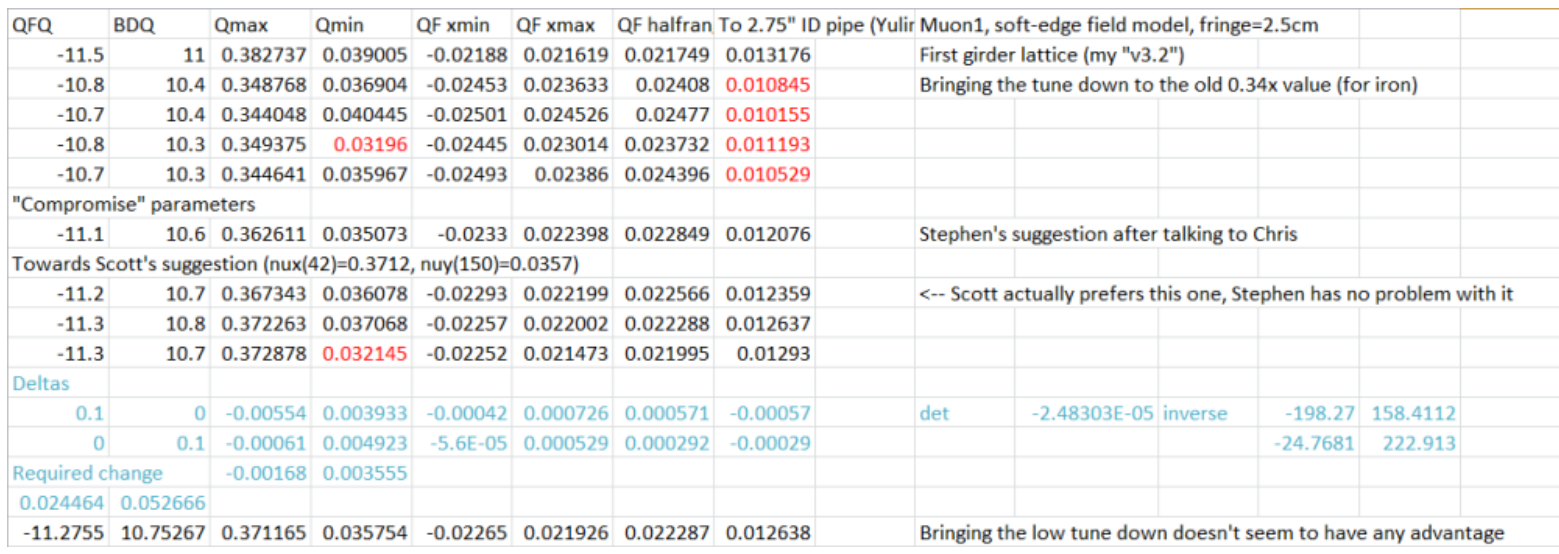

Low tunes were initially tried that emulated the $0.34 x$ cell tune of the iron lattice, but these produced orbit excursions that were too large. A compromise was found that retained the $12 \mathrm{~mm}$ clearance and finally Scott Berg suggested going even higher in tune as this gave an operating point that had some flexibility to jump over a resonance if the linac energy was varied, as a fallback. 